\title{
Antimicrobial activity of Trembleya laniflora, Xyris platystachia and Xyris pterygoblephara
}

\author{
Claiton Pires Ventura, Alaíde Braga de Oliveira, Fernão Castro Braga* \\ Faculdade de Farmácia, Universidade Federal de Minas Gerais, Av. Antônio Carlos 6627, \\ Campus Pampulha, 31270-901, Belo Horizonte, MG, Brazil
}

\begin{abstract}
RESUMO: "Atividade antimicrobina de Trembleya laniflora, Xyris platystachia e Xyris pterygoblephara". As espécies Trembleya laniflora (Melastomataceae), Xyris platystachia (Xyridaceae) e Xyris pterygoblephara foram coletadas na Serra do Cipó, região considerada hotspot para conservação de biodiversidade. A atividade antimicrobiana dessas espécies foi avaliada em ensaios in vitro de difusão em ágar frente a linhagens padronizadas de Staphylococcus aureus e Micrococcus luteus. Todos os extratos, avaliados na concentração de $2000 \mu \mathrm{g} / \mathrm{disco}$, foram ativos contra $M$. luteus, enquanto a inibição de crescimento de $S$. aureus somente foi observada para os extratos de T. laniflora (folhas) e X. platystachia (partes aéreas). A partição dos extratos brutos entre solventes imiscíveis resultou na obtenção de frações ativas, oriundas de extratos originalmente inativos frente a $S$. aureus, observando-se atividade principalmente para as frações de baixa e média polaridade. $\mathrm{O}$ extrato de folhas de $T$. laniflora foi adicionalmente fracionado por cromatografia em coluna de sílica gel e as frações resultantes apresentaram atividade antimicrobiana e perfis por CLAE distintos daquelas obtidas pela partição entre solventes imiscíveis.
\end{abstract}

Unitermos: Trembleya laniflora, Xyris platystachia; Xyris pterygoblephara, atividade antimicrobiana.

\begin{abstract}
Trembleya laniflora (D. Don) Cogn. (Melastomataceae), Xyris platystachia Alb. Nilss. (Xyridaceae) and Xyris pterygoblephara Kunth., Brazilian species collected from a biodiversity hotspot for conservation priority, had their antimicrobial activity evaluated against standardized strains of Staphylococcus aureus and Micrococcus luteus, by the agar diffusion assay. All extracts, assayed in the concentration of $2000 \mu \mathrm{g} / \mathrm{disc}$, were active against $M$. luteus, whereas $S$. aureus growth was inhibited only by $T$. laniflora leaves and X. platystachia aerial parts. Fractionation of the extracts by partition between immiscible solvents resulted in active fractions from extracts originally inactive against $S$. aureus. Activity was mainly found in low and medium polar fractions. The extract of $T$. laniflora leaves was also fractionated by silica gel column chromatography and both the HPLC fingerprint and antimicrobial activity of the obtained fractions were distinct of those originated from the partition process.
\end{abstract}

Keywords: Trembleya laniflora, Xyris platystachia, Xyris pterygoblephara, antimicrobial activity.

\section{INTRODUCTION}

Brazil is recognized as one of the megadivesity countries, concentrating around 10 to $20 \%$ of all plant species in the world (Mittermeier et al., 1997). A total of 10,000 plant species are estimated to occur in Minas Gerais (Mendonça; Lins, 2000). Serra do Cipó is a national park located in this state, in a region classified as a biodiversity hotspot for conservation priority (Myers et al., 2000). The area presents exceptional concentrations of endemic species and is experiencing loss of habitats, contributing to drive many species into extinction. We have previously investigated the antifungal and antibacterial activity of 20 plant species from Serra do Cipó (Cota et al., 2002). Among the active species, three were selected for study in the present work.

Trembleya laniflora (Melastomataceae) is a shrub popularly named "flor-de-lã" (wool flower), used as ornamental species (Pio Corrêa, 1969). T. laniflora grows mainly in rocky soils from campos rupestres, an altitudinal ecosystem covered by open vegetation, being the genus endemic in Brazil. A chemotaxonomic study carried out for the leaves of Melastomataceae species, belonging to the closely related genera Lavoisiera, Microlicia and Trembleya, resulted in the identification of 116 flavonoids, comprising 69 flavonol and 47 flavone glycosides, including kaempferol 3-O-glycosides and quercetin 3-O-glycosides in T. laniflora (Bomfim-Patrício et al., 2001). A literature search indicated no ethnomedical use or biological activity other than antimicrobial described for T. laniflora (Cota et al., 2002).

Xyris species are small shrubs, popularly known as "sempre-vivas" (everlasting plants). Some are collected for ornamental purposes or for medicinal 
uses, to treat eczemas and dermatitis (Pio Corrêa, 1969). The identification of Xyris species based solely on morphological characters is rather limited (Varanda et al., 2002). Around $90 \%$ of the Xyris found in Brazil are endemic (Sajo et al., 1997) and over harvesting has put several species in risk of extinction.

The chemistry and biological activity of Xyris have been poorly investigated. Metabolites obtained from this genus include isocoumarins from $X$. indica (Ruangrungsi et al., 1995), anthraquinones from $X$. semifuscata (Fournier et al., 1975) and flavonoids from $X$. itatiayensis, $X$. longiscapa and $X$. obtusiuscula (Varanda et al., 2002). Recently, we reported the isolation of a new anthraquinone from $X$. pilosa, active against Fusarium oxysporum (Cota et al., 2004). Except the antimicrobial effect (Cota et al., 2002; Cota et al., 2004), no other biological activity or any chemical data has been described for X. platystachia and X. pterygoblephara, species selected for the study.

The diversity of compounds found in plant species make these organisms promising sources of new antimicrobial agents, with general or specific effects (Amaral et al., 2006; Leitão et al., 2006). The interest in plant secondary metabolites with antimicrobial properties has revived as a consequence of microbial resistance development against the antibiotics in clinical use (Rocha et al., 2004; Lima et al., 2006; Oliveira et al., 2006), especially in the case of opportunistic infections affecting immunocompromised patients (Klausmeyer et al., 2004). Considering that the species selected for the study occur in an ecosystem with a high degree of endemism, it is feasible to infer that they are a potential source of bioactive compounds. Hence, the main goal of this work was to assay the antimicrobial activity of extracts and fractions from T. laniflora, X. platystachia and X. pterygoblephara.

\section{MATERIAL AND METHODS}

\section{Plant materials}

The species Trembleya laniflora (D. Don) Cogn., Xyris pterygoblephara Kunth. and Xyris platystachia Alb. Nilss. were collected in Minas Gerais state, Brazil, at Serra do Cipó National Park and APA Morro da Pedreira. The plants were identified by botanists from the Fundação Zoo-Botânica, Belo Horizonte, Brazil, where voucher specimens are deposited, under numbers BHZB 2340, BHZB 2496 and BHZB 2492, respectively.

\section{Plant material extraction and preliminary fractionation}

The plants were dried separately, at $40{ }^{\circ} \mathrm{C}$, for $72 \mathrm{~h}$. The extracts of T. laniflora (leaves, stems), $X$. pterygoblephara (aerial parts) and X. platystachia (aerial parts) were prepared by exhaustive percolation with ethanol. The extracts were concentrated to residue by removing the solvents in a rotavapor, at $50{ }^{\circ} \mathrm{C}$. Data obtained for the dry extracts are shown in Table 1. Portions $(2 \mathrm{~g})$ of the dry extracts were suspended in $\mathrm{MeOH} / \mathrm{H}_{2} \mathrm{O}$ $(1: 1 ; 120 \mathrm{~mL})$ and sequentially partitioned with equal volumes $(120 \mathrm{~mL})$ of $n$-hexane, $\mathrm{CH}_{2} \mathrm{Cl}_{2}$ and EtOAc. $\mathrm{MeOH}$ was removed in a rotavapor, before partitioning the extract suspension with $\mathrm{CH}_{2} \mathrm{Cl}_{2}$ and EtOAc. Solvents were removed in a rotatory evaporator, at maximum temperature of $50{ }^{\circ} \mathrm{C}$, and the obtained residues are displayed in Table 2. Emulsions were generated during the partition of the extract from T. laniflora leaves between $n$-hexane (Emulsion 1), dichloromethane (Emulsion 2) and ethyl acetate (Emulsions 3 and 4). HPLC analysis carried out for the emulsions indicated distinct profiles from the obtained fractions and for this reason they were concentrated separately and had their residues evaluated in the antimicrobial assays.

\section{Chromatographic fractionation of the extract from $T$. lanifora leaves}

The crude extract of $T$. laniflora leaves $(22.8$ g) was chromatographed on a silica gel column (70-230 mesh, Merck), employing a gradient elution of $n$-hexane (79.6 mg, TL1), $n$-hexane: $\mathrm{CH}_{2} \mathrm{Cl}_{2}$ (1:1) (361.7 mg, TL2), $\mathrm{CH}_{2} \mathrm{Cl}_{2}$ (689.4 mg, TL3), $\mathrm{CH}_{2} \mathrm{Cl}_{2}$ :EtOAc (1:1) (1639.3 mg, TL4; $1239.7 \mathrm{mg}$, TL5), EtOAc (2205.2 mg, TL6), $\mathrm{MeOH}(80.9 \mathrm{mg}$, TL7; $11589.8 \mathrm{mg}$, TL8) and $\mathrm{MeOH}$ : $\mathrm{H}_{2} \mathrm{O}(1: 1)$ (1201.6 mg, TL9).

\section{Bacterial cultures and growth conditions}

Staphylococcus aureus ATCC 25923 and Micrococcus luteus ATCC 9341 were employed as test organisms. The cultures were grown in agar medium, in tubes kept in a slating position, at $36^{\circ} \mathrm{C}$, for $24 \mathrm{~h}$. Cultures were maintained in plates, at $4^{\circ} \mathrm{C}$, in $\mathrm{n}^{\circ} 1$ antibiotic agar.

\section{Antimicrobial assay}

The antibacterial activity of extracts and fractions was evaluated by the disk diffusion method. For the assays, solutions of the extracts and fractions were prepared in $\mathrm{MeOH}$ to concentrations of 100 and $50 \mathrm{mg} /$ $\mathrm{mL}$, respectively. Suspensions of microorganisms were prepared in peptone saline solution. The transmittance of the inoculum suspension was adjusted to $50 \pm 1 \%$, at $580 \mathrm{~nm}$. Seeded agar plates were prepared by pouring 20 $\mathrm{mL}$ of $\mathrm{n}^{\circ} 1$ antibiotic agar into each plate. After medium solidification, each plate was overlaid with $5 \mathrm{~mL}$ medium containing $0.05 \%$ of the inoculum suspension. Sterile paper discs (6 mm diameter) were impregnated with 20 $\mu \mathrm{L}$ of the extracts $(2000 \mu \mathrm{g} / \mathrm{disc})$ or fractions $(1000 \mu \mathrm{g} /$ disc). The discs were placed in duplicate onto the plates and incubated for $24 \mathrm{~h}$, at $37^{\circ} \mathrm{C}$. The experiments were carried out in six replicates. The results (mean value 
Table 1. Ethanol extractives obtained from the plants in study.

\begin{tabular}{lllll}
\hline Plant name & Part & $\begin{array}{l}\text { Dry vegetal } \\
\text { material }(\mathrm{g})\end{array}$ & Dry extract $(\mathrm{g})$ & Extractive $(\%)$ \\
\cline { 2 - 5 } Xyris pterygoblephara & Aerial parts & 43.3 & 4.30 & 9.93 \\
Xyris platystachia & Aerial parts & 100.0 & 13.31 & 13.31 \\
Trembleya laniflora & Leaves & 200.0 & 28.50 & 14.25 \\
& Stems & 100.0 & 15.34 & 15.34 \\
\hline
\end{tabular}

Table 2. Fractions resulting from partition of plant extracts between immiscible solvents.

\begin{tabular}{|c|c|c|c|c|c|c|c|c|c|}
\hline \multirow{2}{*}{ Plant extract (2 g) } & & \multicolumn{8}{|c|}{ Fractions (mg) } \\
\hline & Part & Hex & $*_{\mathrm{Em} 1}$ & DCM & *Em2 & EtOAc & $*_{\mathrm{Em} 3}$ & $*_{\mathrm{Em} 4}$ & Water \\
\hline Xyris pterygoblephara & $\begin{array}{l}\text { Aerial } \\
\text { parts }\end{array}$ & 365.3 & & 146.3 & & 518.5 & & & 1016.5 \\
\hline Xyris platystachia & $\begin{array}{l}\text { Aerial } \\
\text { parts }\end{array}$ & 164.5 & & 142.8 & & 467.8 & & & 1051.3 \\
\hline Trembleya laniflora & $\begin{array}{l}\text { Leaves } \\
\text { Stems }\end{array}$ & $\begin{array}{l}158.1 \\
80.0\end{array}$ & 98.7 & $\begin{array}{l}164.7 \\
44.6\end{array}$ & 338.4 & $\begin{array}{l}83.9 \\
67.6\end{array}$ & 65.0 & 55.8 & $\begin{array}{l}716.7 \\
1392.8\end{array}$ \\
\hline
\end{tabular}

*Emulsions formed during the partition process. See experimental for details.

Table 3. Antimicrobial activity of plant ethanol extracts and fractions obtained by partition of crude extract between immiscible solvents, assayed by the agar diffusion method.

\begin{tabular}{|c|c|c|c|c|}
\hline \multirow[t]{2}{*}{ Plant extract } & \multirow[t]{2}{*}{ Part } & \multirow[t]{2}{*}{ Extract / fractions } & \multicolumn{2}{|c|}{$\begin{array}{c}\text { Microbial inhibition } \\
(\mathrm{mm} \text { diameter zone } \pm \mathrm{rsd})\end{array}$} \\
\hline & & & M. luteus & S. aureus \\
\hline \multirow[t]{14}{*}{ Trembleya laniflora } & stems & ${ }^{\mathrm{a}}$ crude extract & $9.2 \pm 0.3$ & $b_{-}$ \\
\hline & & $n$-hexane & $12.8 \pm 1.0$ & $9.0 \pm 0.0$ \\
\hline & & DCM & $11.5 \pm 0.5$ & $9.3 \pm 0.3$ \\
\hline & & EtOAc & $13.5 \pm 0.9$ & $10.2 \pm 0.6$ \\
\hline & & water & - & - \\
\hline & leaves & crude extract & $12.8 \pm 0.6$ & $9.5 \pm 0.5$ \\
\hline & & $n$-hexane & $21.0 \pm 0.9$ & $14.3 \pm 0.8$ \\
\hline & & Emulsion 1 & $13.0 \pm 0.9$ & $10.2 \pm 0.3$ \\
\hline & & DCM & $16.2 \pm 0.8$ & $14.2 \pm 0.8$ \\
\hline & & Emulsion 2 & $12.7 \pm 0.8$ & $8.3 \pm 0.8$ \\
\hline & & EtOAc & $13.2 \pm 0.6$ & $12.7 \pm 0.3$ \\
\hline & & Emulsion 3 & - & $8.2 \pm 0.3$ \\
\hline & & Emulsion 4 & $7.3 \pm 0.3$ & - \\
\hline & & water & $9.2 \pm 0.6$ & - \\
\hline \multirow[t]{5}{*}{ Xyris platystachia } & aerial parts & crude extract & $10.3 \pm 0.8$ & $7.7 \pm 0.6$ \\
\hline & & $n$-hexane & - & - \\
\hline & & $\mathrm{DCM}$ & $12.2 \pm 0.8$ & $11.2 \pm 0.7$ \\
\hline & & EtOAc & $9.7 \pm 0.3$ & - \\
\hline & & water & - & - \\
\hline \multirow{5}{*}{ Xyris pterygoblephara } & aerial parts & crude extract & $10.0 \pm 0.5$ & - \\
\hline & & $n$-hexane & - & - \\
\hline & & DCM & $9.2 \pm 0.6$ & $8.3 \pm 0.3$ \\
\hline & & EtOAc & $11.0 \pm 0.5$ & $7.7 \pm 0.6$ \\
\hline & & water & - & - \\
\hline Chloramphenicol & & & $21.0 \pm 0.9$ & $12.6 \pm 0.7$ \\
\hline
\end{tabular}

aPaper discs were impregnated with $2000 \mu \mathrm{g}$ of the extracts or $1000 \mu \mathrm{g}$ of the fractions.

b(-) no detected activity at the assayed concentrations. $\mathrm{MeOH}$ (control) did not show any inhibitory activity. 
Table 4. Antimicrobial activity of chromatographic fractions from the extract of Trembleya laniflora leaves, assayed by the agar diffusion method

\begin{tabular}{lcc}
\hline \multirow{2}{*}{ Fractions } & \multicolumn{2}{c}{$\begin{array}{c}\text { Microbial inhibition } \\
\text { (mm diameter zone } \pm \text { rsd) }\end{array}$} \\
\hline TL1 (n-hexane) & M. luteus & - \\
TL2 (DCM: -hexane, 1:1) & b & - \\
TL3 (DCM) & - & - \\
TL4 (DCM:EtOAc, 1:1) & - & - \\
TL5 (DCM:EtOAc, 1:1) & $14.0 \pm 0.9$ & $9.2 \pm 0.8$ \\
TL6 (EtOAc) & $20.0 \pm 0.5$ & $8.5 \pm 0.0$ \\
TL7 (MeOH) & $12.7 \pm 1.0$ & $7.8 \pm 0.6$ \\
TL8 (MeOH) & $8.6 \pm 1.0$ & - \\
TL9 (MeOH:water, 1:1) & - & - \\
Chloramphenicol & - & $10.5 \pm 0.7$ \\
\hline
\end{tabular}

apaper discs were impregnated with $1000 \mu \mathrm{g}$ of the fractions.

$\mathrm{b}(-)$ no detected activity at the assayed concentrations. $\mathrm{MeOH}$ (control) did not show any inhibitory activity.

plus standard deviation) were recorded by measuring the zones of growth inhibition surrounding the discs. Chloramphenicol ( $3 \mu \mathrm{g} / \mathrm{disc})$ was included in the assays as positive control, whereas control disks contained solvent only $(\mathrm{MeOH})$ as negative control.

\section{HPLC characterization of fractions}

Analysis were carried out on a Merck-Hitachi apparatus (Germany) composed of pump L-6200A, automatic injector AS-2000A, UV-VIS detector L4250 and integrator D-2500. An ODS column $(150 \times$ $4.0 \mathrm{~mm}$ I.D., $5 \mu \mathrm{M}$ ) was employed (Merck, Germany) at a temperature of $40{ }^{\circ} \mathrm{C}$ and flow rate of $1.0 \mathrm{~mL} / \mathrm{min}$. Analysis were performed at $220 \mathrm{~nm}$. A linear gradient of $\mathrm{H}_{2} \mathrm{O}(\mathrm{A})$ and $\mathrm{CH}_{3} \mathrm{CN}$ (B) was employed: 0 min $90 \%$ A, $10 \%$ B; 60 min $10 \%$ A, $90 \%$ B, followed by $10 \mathrm{~min}$ of isocratic elution. Solvents used were of HPLC grade (Merck, Germany) and were degassed by sonication before use. Fractions were dissolved in $\mathrm{MeOH}$ to a concentration of $5 \mathrm{mg} / \mathrm{mL}$. After centrifugation at 10,000 r.p.m, the sample solutions $(30 \mu \mathrm{L})$ were automatically injected.

\section{Phytochemical analysis}

The presence of saponins, alkaloids, coumarins, anthraquinones, flavonoids, triterpenes and tannins was evaluated in the ethanol extracts, by TLC analysis, according to Wagner et al. (1984).

\section{RESULTS AND DISCUSSION}

The ethanol extracts of Trembleya laniflora,
Xyris platystachia and Xyris pterygoblephara have been previously evaluated in antimicrobial assays, against different strains of bacteria and fungi (Cota et al., 2002; Cota et al., 2004). The three species were particularly active against $S$. aureus and M. luteus, and for this reason both were selected as test organism in the present work. Aliquots from the crude ethanol extracts were initially fractionated by partition between immiscible solvents and the obtained results are displayed in Table 2.

All assayed extracts were active against $M$. luteus, whereas $S$. aureus growth was inhibited only by the extracts from $T$. laniflora leaves and $X$. platystachia aerial parts. In the previous work (Cota et al., 2002), the extracts from $T$. laniflora stems and $X$. pterygoblephara aerial parts were active against $S$. aureus, while $X$. platystachia did not show inhibitory effect against this microorganism. Such contradictory results may be explained by differences in extract compositions, since the plant materials were collected in distinct locations.

Phytochemical analysis (Wagner et al., 1984) of the ethanol extracts gave positive results for saponins, triterpenes and tannins. Flavonoids were also detected in the three species, except in the stems of T. laniflora, whereas coumarins were solely present in the aerial parts of $X$. platystachia and X. pteryglobephara. Several flavonoids (Harborne; Williams, 2002), coumarins (Borges et al., 2005), tannins (Chung et al., 1998), saponins (Wallace, 2004) and triterpnes (Katerere et al., 2003) have been reported to posses antimicrobial activity. Therefore, the presence of metabolites from these classes in the assayed species might explain their antimicrobial activity here reported.

The four extracts were submitted to preliminary fractionation by partition between immiscible solvents and the resulting fractions had their antimicrobial 
(a)

(b)
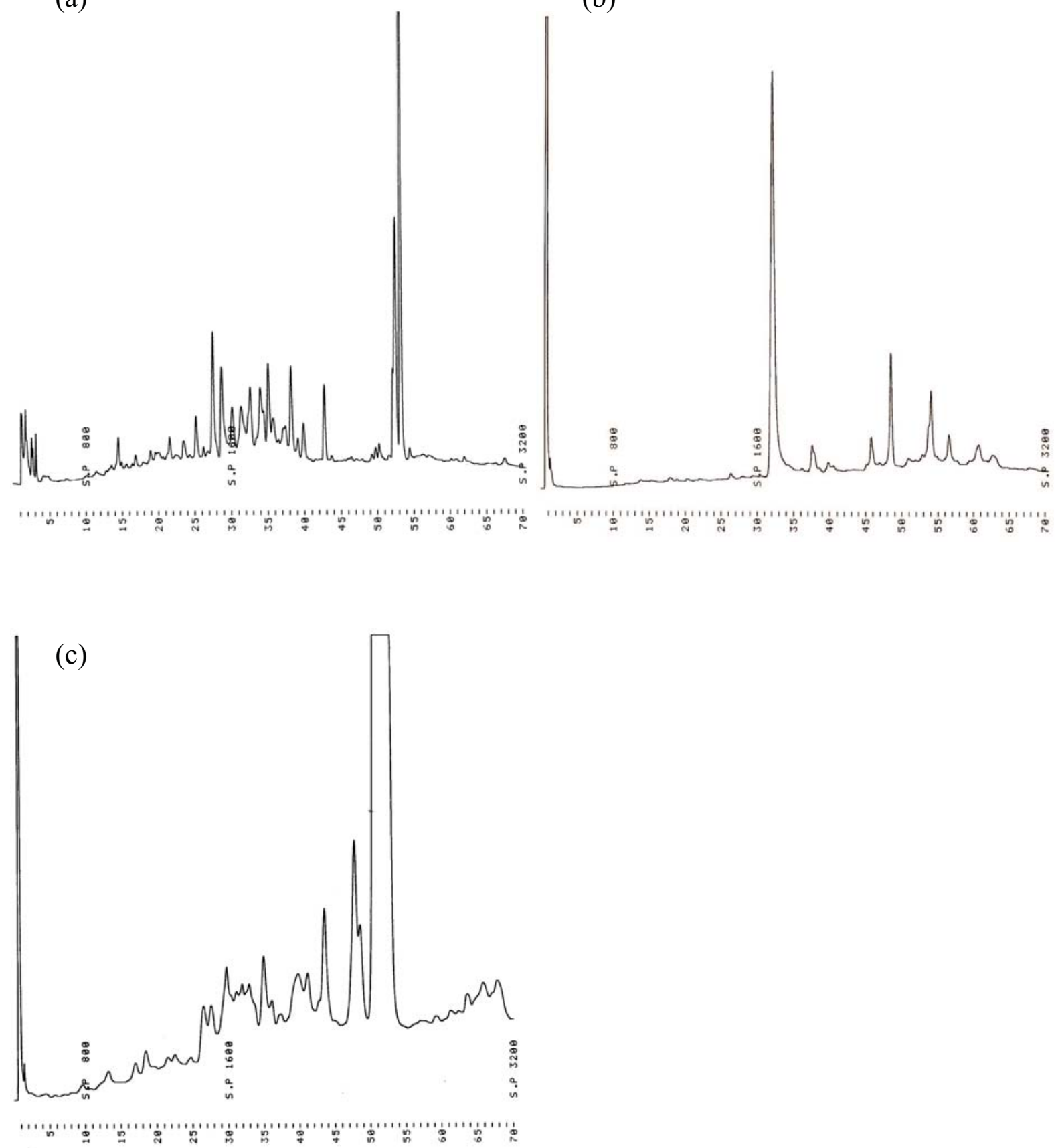

Figure 1. HPLC profiles of fractions from Trembleya laniflora leaves. (a) Dichloromethane fraction obtained by partition between immiscible solvents; (b) dichloromethane (TL3) and (c) dichloromethane / ethyl acetate (1:1) (TL4) fractions from silica gel column chromatography. HPLC conditions: see experimental.

activity evaluated. Active fractions were obtained from extracts originally inactive against $S$. aureus (Table 3). This result demonstrates the importance of a preliminary fractionation when assaying the antimicrobial activity of plant extracts, once the low concentration of the active compounds may impair their detection in crude extracts.

Partition between immiscible solvents is an adequate approach for the preliminary separation of complex matrices, such as vegetal extracts. However, scaling up this procedure to obtain quantities of material for further studies is frequently time consuming and production of emulsions is almost impossible to avoid. Fractionation by silica gel column chromatography constitutes an alternative to overcome these limitations. It should be reminded, however, that different physical phenomena are involved in these procedures, namely 
solubility in the first and adsorption in the second. Hence, applying these methods to the same matrix might result in fractions with distinct compositions and activities.

In order to confirm this supposition, fingerprint profiles were registered by HPLC for fractions of the extract from T. laniflora leaves obtained by partition between immiscible solvents and by fractionation on a silica gel column. Besides, the antimicrobial activity of the chromatographic fractions was also assayed.

Dichloromethane fractions originated from both approaches showed distinct HPLC profiles (Figure 1) and antimicrobial effects: while the fraction obtained by partition was significantly active against $M$. luteus and $S$. aureus (Table 3), the chromatographic one (TL3) showed no activity against both microorganisms (Table 4). On the other hand, HPLC analysis of the dichloromethane / ethyl acetate (1:1) fraction (TL4), originated from the chromatographic fractionation, showed a more related profile to that of the dichloromethane fraction obtained by partition between immiscible solvents (Figure 1). However, TL4 was active solely against M. luteus. These results clearly confirm our hypothesis that fraction constitution, and therefore biological activity, depends on the procedure adopted for fractionation.

In conclusion, the results here reported corroborate the popular use of the species to treat microbial diseases and also demonstrate the relevance of a preliminary fractionation for detecting active fractions, when assaying the antimicrobial effect of plant extracts.

\section{ACKNOWLEDGEMENTS}

This work was financed by funds from Fundo Fundep, UFMG, Brazil. CNPq is also acknowledged for a research fellowship (F.C.B.).

\section{REFERENCES}

Amaral FMM, Ribeiro MNS, Barbosa-Filho JM, Reis AS, Nascimento FRF, Macedo RO 2006. Plants and chemical constituents with giardicidal activity. Rev Bras Farmacogn 16(Supl.): 696-720.

Bomfim-Patrício MC, Salatino A, Martins AB, Wurdack JJ, Salatino MLF 2001. Flavonoids of Lavoisiera, Microlicia and Trembleya (Melastomataceae) and their taxonomic meaning. Biochem Syst Ecol 29: 711726.

Borges F, Roleira F, Milhazes N, Santana L, Uriarte E 2005. Simple coumarins and analogues in medicinal chemistry: occurrence, synthesis and biological activity Curr Med Chem 12: 887-916.

Chung KT, Wong TY, Wei CI, Huang YW, Lin Y 1998. Tannins and human health: a review. Crit Rev Food Sci Nutr 38: 421-464.

Cota BB, Oliveira AB, Ventura CP, Mendonça MP, Braga FC 2002. Screening for antimicrobial activity of plant species from a Brazilian hotspot for conservation priority. Pharm Biol 40: 542-547.

Cota BB, Oliveira AB, Guimarães KG, Mendonça MP, Souza
Filho JD, Braga FC 2004. Chemistry and antifungal activity of Xyris species (Xyridaceae) a new antraquinone from Xyris pilosa. Biochem Syst Ecol 32: 391-397.

Fournier G, Bercht CAL, Paris RR, Paris MR 1975. 3Methoxychrysazin, a new antraquinone from Xyris semifuscata. Phytochemistry 14: 2099.

Harborne JB, Williams CA 2000. Advances in flavonoids research since 1992. Phytochemistry 55: 481-504.

Katerere DR, Gray AI, Nash RJ, Waigh RD 2003. Antimicrobial activity of pentacyclic triterpenes isolated from African Combretaceae. Phytochemistry 63:81-88.

Klausmeyer P, Chmurny GN, McCloud TG, Tucker KD, Shoemaker RH 2004. A novel antimicrobial indolizinium alkaloid from Aniba panurensis. $J$ Nat Prod 67: 1732-1735.

Leitão SG, Castro O, Fonseca EM, Julião LS, Tavares ES, Leo RRT, Vieira RC, Oliveira DR, Leitão GG, Martino V, Sulsen V, Barbosa YAG, Pinheiro DPG, Silva PEA, Teixeira DF, Lourenço MCS 2006. Screening of Central and South American plant extracts for antimycobacterial activity by the Alamar Blue test. Rev Bras Farmacogn 16: 6-11.

Lima MRF, Ximenes CPA, Luna JS, Sant'Ana AEG 2006. The antibiotic activity of some Brazilian medicinal plants. Rev Bras Farmacogn 16: 300-306.

Mendonça MP, Lins LV 2000. Lista vermelha das espécies ameaçadas de extinção da flora de Minas Gerais. Belo Horizonte: Fundação Biodiversitas, Fundação Zoo-Botânica de Belo Horizonte.

Mittermeier RA, Gil PR, Mittermeier CG 1997. Megadiversity: Earth's Biologically Wealthiest Nations. México City: CEMEX, Agrupacíon Sierra Madre.

Myers N, Mittermeier RA, Mittermeir CG, Fonseca GAB, Kent J 2000. Biodiversity hotspots for conservation priorities. Nature 403: 853-858.

Oliveira RAG, Lima EO, Vieira WL, Freire KRL, Trajano VN, Lima, IO, Souza EL, Toledo MS, Silva-Filho RN 2006. Estudo da interferência de óleos essenciais sobre a atividade de alguns antibióticos usados na clínica. Rev Bras Farmacogn 16: 77-82.

Pio Corrêa M 1969. Dicionário de plantas úteis do Brasil e das exóticas cultivadas. Rio de Janeiro: Di Giorgio.

Rocha AD, Oliveira AB, Souza Filho JD, Lombardi JA, Braga FC 2004. Antifungal constituents of Clytostoma ramentaceum and Mansoa hirsuta. Phytother Res 18: 463-467.

Ruangrungsi N, Toshikazu S, Phadungcharoent T, Suriayagan S, Murakoshi I 1995. Isocoumarins from Xyris indica. Phytochemistry 38: 481-483.

Sajo MG, Wanderley MGL, Menezes NL 1997. Observações anatômicas sobre a vascularização floral em Xyris L. (Xyridaceae). Bol Bot USP 16: 15-19.

Varanda EM, Rondinoni C, dos Santos DYAC 2002. Flavonoids from Xyris species (Xyridaceae). Biochem Syst Ecol 30: 997-998.

Wagner H, Bladt S, Zgainski EM 1984. Plant drug analysis. Berlin: Springer-Verlag.

Wallace RJ 2004. Antimicrobial properties of plant secondary metabolites Proc Nutr Soc 63: 621-629. 